\title{
Consumers' Perception of CSR Activities: What Does it Mean for Companies?
}

DOI: 10.7595/management.fon.2021.0017

Abstract:

Research Question: The paper develops a conceptual model for exploring the factors which impact the consumers' word of mouth (WOM) and willingness to pay (WTP) for products and services of socially responsible companies. Motivation: The paper is based on the research of Castaldo et al. (2009), Pivato et al. (2007), Rim and Kim (2016), and Jarvis et al. (2017) concerning the consumers' perception of corporate social responsibility (CSR) and measurement of the effectiveness of CSR activities. Accordingly, our paper tries to provide companies with valuable information on how the consumers' perception of CSR activities impacts the consumers' trust, awareness, purchase intention, and future behaviour. Idea: The proposed model is based on three pillars: Perception of CSR, Moderating effects, and Willingness to pay and recommend and strives to shed light on their mutual relations. The goal is to better understand the complex mechanisms and consequences of the consumers' perception of CSR activities of companies. Data: To verify the proposed conceptual model, a questionnaire was developed and distributed. In total, 265 respondents participated in the research. Tools: Structural equation modelling (SEM) analysis was employed to explore the relationships between defined factors. Findings: The findings illustrate that both attitudes towards CSR and CSR companies have an impact on the level of trust and purchase intention. When it comes to WTP and WOM, only the level of trust and purchase intention have an impact. Interestingly, the respondents' awareness of the companies' CSR activities did not have an impact on WTP and WOM. The model indicates that the companies should communicate their CSR activities which will lead to greater trust and purchase intention leading to higher consumers' willingness to pay and recommend the companies' products/services. Contribution: The study empirically explores how the perception of CSR and CSR activities potentially influences the WOM and WTP on products and services of socially responsible companies and provides a roadmap on how companies can increase the benefits of their CSR activities.

Keywords: corporate social responsibility, conceptual model, consumer awareness, WOM, WTP

JEL Classification: M14, M31, C38, C52

\section{Introduction}

The sphere of corporate social responsibility (CSR) and social responsibility is a prevalent subject in this century, especially in the Covid-19 era. Nevertheless, the term dates back to the distant past, as back as the Roman Empire when people organised in groups that had a powerful social impact and helped the homeless, poor, and ill (Chaffee, 2017). In today's business, during the pandemics, the CSR activities encompass making dollar contributions to support medical care workers, food banks, and schools, providing free laptops for children learning from home, phone chargers to hospitals so that patients and workers could stay in touch with their loved ones more easily, and others (Manuel \& Herron, 2020).

According to Porter and Kramer (2006), there are four main reasons why companies should turn to adopting the concept of CSR in their business practices: moral obligation, sustainability, license to operate, and reputation. The aspect on which this study focuses is reputation. Namely, previous research showed that

*Corresponding author: Milica Nikolić, e-mail: milica.nikolic.ssfon@gmail.com 
CSR activities might lead to competitive advantage, better relations with stakeholders, employees, and consumers, corporate image, and corporate reputation (Almeida \& Coelho, 2019). Therefore, it is in the company's interest to engage in CSR to improve its reputation and recognition.

Although there are many reasons and benefits for a company to engage in CSR, the issue that emerges is how to measure the company-specific value of CSR activities. CSR effects can be hard to identify and measure. Different approaches have been proposed: composite indicators (Maricic \& Kostic-Stankovic, 2016), impact models (Weber, 2008), conceptual models (Castaldo et al., 2009), various key performance indicators (Ekatah et al., 2011), and others.

The research question this study strived to answer is how to measure and explore the effects of consumers' perception of CSR and businesses of companies who are socially responsible. In this vein, the authors created a three-pillar conceptual model and tested the relationships between Perception of CSR (measured through Attitude towards CSR and Attitude towards CSR companies), Moderating effects (measured through Awareness, Trust, and Purchase Intention), and Willingness to pay (WTP) and Word of mouth (WOM). The proposed model attempts to integrate several concepts, improve the currently devised ones and fill in the gaps in the CSR literature.

The paper is organised as follows: the next section reviews several previously defined conceptual models on the topic of CSR, while Section 3 focuses on the in-depth introduction of the proposed conceptual model and the rationale for its construction. The following section covers the conducted research, model verification, and managerial implications of the obtained results. Section 5 sees the concluding remarks.

\section{Measuring the Consumers' Attitude towards Companies which Engage in CSR Activities}

Companies that engage in CSR activities require feedback on the effectiveness of their CSR projects. Just some of the questions which arise are: Has the perception of the company and its products/services changed because of the conducted CSR activities? Do CSR activities impact sales? How does the public observe the company for its CSR activities? One of the approaches to answering these questions is a conceptual model development and its verification using a structural equation modelling (SEM) analysis. Herein, we will present a number of models which acted as a guide for the development of our model.

Castaldo et al. (2009) in their research examined the missing link between CSR and consumer trust in the case of Fair Trade products. They used five constructs in their model: Consumer CSR, Trust in Fair Trade, Trust in retailer private-label Fair Trade products, Brand loyalty and Willingness to pay a premium price. They concluded that the reputation of a retailer for respecting the rights of consumers and satisfying their needs positively adds to the trust of consumers toward Fair Trade products. Also, they confirmed the hypotheses that consumers will pay a higher price and be loyal to Fair Trade products.

Pivato et al. (2007) researched the impact of CSR on consumer trust in the case of organic food. Their structural model examined the link between the corporate social performance of retailers, trust in organic products, trust in private-label organic products and brand loyalty in private-label organic products. They tested three hypotheses, and the results provided strong support for all of them. The assumption that consumer perception of CSR performance is positively related to trust in organic products was confirmed. Also, they concluded that trust in organic products correlated positively with trust toward private-label organic products and that trust in private-label organic products positively correlated with brand loyalty.

Rim and Kim (2016) analyzed the dimensions of CSR skepticism and their impacts on public evaluations toward CSR. Using SEM analysis, they evaluated links between skepticism toward informativeness, disbelief, skepticism toward altruism, and cynicism. They concluded that skepticism toward altruism was a significant predictor for supportive behavioural intentions and consumers' attitude toward companies. The disbelief factor and informativeness factor were identified as significant predictors for negative consumer attitudes toward companies. One more significant conclusion is that the higher the public's skepticism toward informativeness and the higher disbelief the public attributes to corporate CSR activity and CSR communication, the more negative attitudes toward companies they develop.

Customer engagement in CSR was examined by Jarvis et al. (2017). They made a model containing six constructs: CSR initiative preference, customer engagement in CSR, customer loyalty, age, gender, and length of time as member. They concluded that there is a positive relationship between a member's prefe- 
rence for a CSR initiative and their intention to be loyal to the sports club and between a member's preference for the CSR initiative and their intention to be engaged in the CSR initiative. Also, the positive link between a member's intention to be engaged with the preferred CSR initiative and their intention to be loyal to the sports club was proven. Engagement with the preferred CSR initiative mediates the relationship between a member's preference for the CSR initiative and their intention to be loyal to the sports club.

\section{Proposed Conceptual Model}

In this section, the proposed conceptual model which strives to quantify the effects of different factors on the perception and purchase intention of products and services of companies which are socially responsible will be presented. The model is based on six constructs, one measured variable and their mutual relations. The respected elements and the related hypothesis are listed below.

\section{Attitude towards CSR}

The first construct of the model has the goal to explore the consumers' attitude towards CSR. It is assumed that the fact the consumer is acquainted with the term CSR and pays attention to CSR activities of companies, it will later affect his/her purchase decision-making. The same viewpoint was held by Marin and Ruiz (2007) who showed that the attitude towards CSR impacts the company-consumer congruence and identity attractiveness and Ramesh et al. (2019) who explored the impact of attitude towards CSR on brand attitude, brand image, and perceived quality.

\section{Attitude towards CSR companies}

It is believed that the attitude towards companies which are or are not socially responsible differs (Mohr \& Webb, 2005). It is assumed that if a consumer has a positive attitude towards socially responsible companies, he/she is going to have trust in the products and services of that company and will be, eventually, willing to pay more. This assumption has been researched by Pivato et al. (2007), who concluded that socially responsible companies could gain a competitive advantage in those economic branches in which trust is the key for choosing consumers. Creyer and Ross (1997) researched the influence of ethical behaviour of companies on the WTP a higher price. They concluded that ethics, as an aspect of socially responsible business, positively impacted the willingness of a consumer to reward that kind of company act and pay a higher price.

\section{Awareness}

Maignan (2001) showed that consumers had little awareness of CSR activities of companies. In the model, Awareness is defined as to how much the respondents recognise companies as CSR active. The fact that the respondent recognizes a company as a socially responsible one indicates that the company has communicated and positioned itself on top of the mind of the respondent which might lead to positive WOM and WTP as shown in the model of Maricic et al. (2019).

\section{Purchase intention}

A purchase intention for buying a specific product depends on many factors. During the purchase decisionmaking process, the term of social responsibility appears in the mind of the consumers. Holmes and Kilbane (1993) conclude that consumers have a more positive attitude about a company if that company makes donations. However, their opinion is that this fact does not influence consumers' intention to buy a product of that company. Later on, Dahl and Lavack (1995) have concluded that the size of donation increases a purchase intention, after all. The findings of this research pointed to the conclusion that the products which showed the donation of the smaller amount of money were less attractive to the consumers and vice versa. The two studies indicate that CSR activities and perception of them can have an impact on purchase intention.

\section{Trust}

Trust is a fundamental asset in every business and non-business relationship (Pivato et al., 2007). The point of view taken in this paper was that consumers have more trust in socially responsible companies. Likewise, our goal was to study how having trust in a company affects other constructs. The assumption was that if the company is socially responsible, a consumer will have more trust in their business, just because the company cares about the community. Castaldo et al. (2009) confirm the assumption that consumers who 
trust in the specific company are accordingly willing to pay a higher price for a product or service of that company. Also, if a consumer trusts a company, it is expected that he/she will share his impressions with other people.

Willingness to pay (WTP)

Willingness to pay a higher price for a specific product or service primarily depends on consumers' priorities and perception. Namely, in some research it is defined as a trade-off that exists when making a purchase decision. The trade-off is between social and traditional features of the product/ service (Marquina \& Morales, 2012). It is believed that the CSR activities of a company can eventually lead to increased WTP. Abrantes Ferreira et al. (2010) show that there is a significant connection between WTP and a purchase intention. Marquina and Morales (2012) showed that CSR could contribute to brand value and customers' higher WTP.

Word of mouth (WOM)

Consumers frequently rely on informal and personal communication sources in making purchase decisions (Bansal \& Voyer, 2000). Recommendations and spreading information influence consumers' opinion and inform them about socially responsible activities of the company, but also on consumers' purchase intention. Yu and Tang (2010), in their research, conclude that WOM will be most favourable when it is positive, richly described and conveyed in a strong manner. East et al. (2008) studied the influence of positive WOM type (PWOM), encouraging brand choice, and negative (NWOM), discouraging brand choice, on purchase intention, and concluded that impact of PWOM was generally greater than NWOM.

\section{Hypotheses and conceptual model}

The proposed conceptual model is given in Figure 1. Accordingly, the model is divided into three pillars: Perception of CSR, Moderating effects, and Willingness to pay and recommend. Based on the literature review, it is hypothesised that there is a positive impact between the pillars:

H1: Perception of CSR has an impact on Moderating effects

H2: Perception of CSR has an impact on Willingness to pay and to recommend

H3: Moderating effects have an impact on Willingness to pay and to recommend

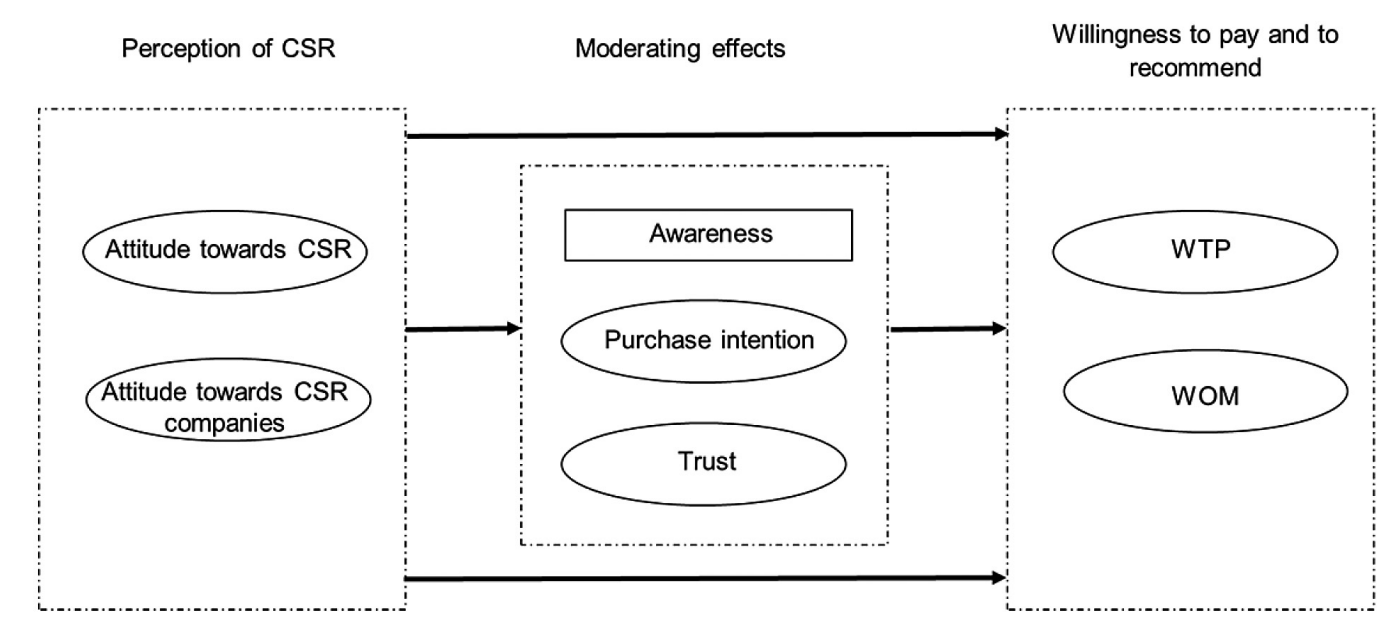

Figure 1: Proposed conceptual model based on three pillars

\section{Conducted research}

\subsection{Procedure, participants, and the survey}

To verify the proposed conceptual model, an online survey was conducted from mid-June until mid-July 2020. The survey was distributed on authors' Linkedln and Facebook profiles. After closing the survey, statistical analysis was performed using SPSS 25 and in AMOS 22. SPSS was used for descriptive statistics, while AMOS was used to verify the structural conceptual model. The survey consisted of eight parts. The first group of questions was related to demographic characteristics of the respondents while the following seven parts 
are related to six constructs and Awareness variable which make the conceptual model. The complete list of questions used to quantify the six constructs alongside the sources from which the questions were adapted from is given in Appendix. All questions which measured the respondents' agreement with specific statements were measured on a four-point Likert scale, ranging from 1 (Strongly disagree) to 4 (Strongly agree).

To measure Awareness of CSR activities, the test of recognition was used. The test of recognition is a standardised test used when measuring the awareness of consumers in marketing research (Stotlar, 1993). In this test, the respondents are expected to point out the companies which they believe have received the "George Weifert" prize awarded by the Chamber of Commerce and Industry of Serbia as the National Award for Corporate Social Responsibility (Privredna komora Srbije, 2020). Regardless of the award itself, this question served to examine the respondents' awareness. If the respondent was not familiar with the award as such and its winners, he/she, based on knowledge of the offered companies, experience with them, knowledge of their CSR activities, should have concluded which companies in his/her opinion could have received this award.

\subsection{Sample characteristics}

The sample consisted of 265 respondents. All questions in the questionnaire were mandatory, so there were no missing data. We had 169 female respondents who make 63.8 per cent of the sample, and 96 male respondents who make 36.2 per cent. The disproportion in the gender of the respondents can be observed. However, such a result should have been expected as females are more prone to participating in online surveys (Smith, 2008). The mean age of the respondents covered by the sample is 26.74 with a standard deviation of 7.747 . This indicates that different target groups are covered by the research. This is also confirmed by looking at the age of the youngest (19) and oldest (69) respondent. Respondents most commonly came from Belgrade (41.5\%) and Serbian cities with 20,000 to 100,000 habitants (27.9\%) as the survey was distributed only in Serbia. Looking at the educational attainment of the respondents, 52.1 per cent of the respondents completed high school, while $36.2 \%$ have a bachelor's degree. Lastly, the household income of the respondents was observed. Most of them have a household income above RSD 100,000 (34.0\%), followed by those with income between 70,000 and RSD 100,00 (23.4\%). It can be observed that the population covered with the sample is urban, student population, and with the household income above average.

\subsection{Results of the test of recognition}

As explained above, in the test of recognition, the respondents had to mark the companies they believed were awarded as extremely socially responsible. In 2019, 15 companies were awarded the "George Weifert" prize for corporate social responsibility. The question itself had 14 answers offered, of which seven were correct and seven were incorrect. Namely, besides the seven companies which have received the "George Weifert" prize, seven companies from the same industries have been offered. The complete list of companies offered is given in Table 1.

The average number of marked companies was 3.92. However, the average number of correct answers of respondents is 2.15 , with a standard deviation of 1.601 . Only eight respondents identified all the correct companies. The rank of companies based on the number of times they were marked as a CSR company and whether the company was the winner of the "George Weifert" prize or not is given in Table 1.

The first thing that can be noticed is that most respondents observe the company DM Drogerie markt as a socially responsible company, 144 (54.3\% of all answers). Considering that this company did receive an award for social responsibility in Serbia, it can be concluded that more than half of the respondents correctly marked at least one company. This result also indicates that the company DM Drogerie markt has managed to present and communicate itself as a socially responsible company to consumers. However, the next two companies which were marked as socially responsible more than 100 times were actually false answers. Namely, 104 (39.2\% of all answers) respondents recognised the company Soko Štark and 101 (38.1\% of all answers) respondents recognised the company Delhaize as socially responsible.

Looking down the list, it can be noticed that two companies have a similar number of responses: TeleGroup (28) and MK Group (29). This is an interesting result, as one of these two companies is the correct answer. In 2019, the company TeleGroup won the "George Weifert" award for socially responsible business in the category of medium-sized companies. 
Table 1: Rank of companies based on the number of times they were marked as a CSR company and whether the company was the winner of the "George Weifert" prize or not

\begin{tabular}{|c|c|c|c|}
\hline Rank & Company & Times marked as a CSR company & True/False winner \\
\hline 1 & DM Drogerie markt & 144 & True \\
2 & Soko Stark & 104 & False \\
3 & Delhaize & 101 & False \\
4 & Telenor & 96 & False \\
5 & NIS & 95 & True \\
6 & Telekom Srbija & 89 & True \\
7 & Metalac & 85 & True \\
8 & Infostud 3 & 81 & True \\
9 & Erste bank & 68 & False \\
10 & Vega IT Sourcing & 48 & True \\
11 & Meridian bet & 45 & False \\
12 & MK Group & 29 & False \\
13 & TeleGroup & 28 & True \\
14 & NCR & 27 & False \\
\hline
\end{tabular}

\subsection{Conceptual model verification}

The next conducted analysis was the verification of the proposed conceptual model. To do so, a SEM analysis was employed. the SEM analysis lays on the theoretical principles of principal component analysis and multiple linear regression (Kline, 2005). This allows the analysis to be two-folded: it reduces the dimensionality of the observed phenomenon, while it allows the exploration of the relation between the newly formed latent factors (Asparouhov \& Muthén, 2009).

When applying the SEM analysis, the literature suggests investigating the internal consistency of the observed constructs. Namely, it should be observed how well the proposed questions measure a particular topic and whether the defined scales are consistent or not. To do so, Cronbach's alpha was used (Cronbach, 1951). Literature suggests that values above 0.700 indicate solid consistency and that the SEM analysis can be conducted (Tavakol \& Dennick, 2011). The obtained Cronbach's alpha per construct and number of questions within each construct are given in Table 2. In our study, the Cronbach's alpha ranges from 0.749 (Purchase intention) to 0.923 (WOM). It can be concluded that all proposed constructs have a satisfactory internal consistency and that the SEM analysis can be conducted.

Table 2: Number of items in each construct and obtained Cronbach's alpha per construct

\begin{tabular}{|c|c|c|c|c|c|c|}
\hline Construct & $\begin{array}{c}\text { Attitude } \\
\text { towards } \\
\text { CSR }\end{array}$ & $\begin{array}{c}\text { Attitude towards } \\
\text { CSR companies }\end{array}$ & $\begin{array}{c}\text { Purchase } \\
\text { intention }\end{array}$ & $\begin{array}{c}\text { Willingness } \\
\text { to pay }\end{array}$ & Trust & WOM \\
\hline $\begin{array}{c}\text { Number of } \\
\text { questions }\end{array}$ & 5 & 6 & 3 & 3 & 3 & 3 \\
\hline $\begin{array}{c}\text { Cronbach's } \\
\text { alpha }\end{array}$ & 0.788 & 0.788 & 0.749 & 0.844 & 0.796 & 0.923 \\
\hline
\end{tabular}

The initial model had a solid fit to the data (Chi-square $=588.548, d f=235, p<0.000, R M S E A=0.075$, $\mathrm{CFI}=0.887, \mathrm{NFI}=0.828, \mathrm{SRMR}=0.1443$ ). Therefore, we used modification indices to fine-tune and enhance our model and removed all paths which were not statistically significant.

The final model had a good fit to the data (Chi-square $=520.668, \mathrm{df}=241, \mathrm{p}<0.000, \mathrm{RMSEA}=0.061$, $\mathrm{CFI}=0.911, \mathrm{NFI}=0.848, \mathrm{SRMR}=0.057)$. The comparative indexes, Comparative Fit Index $(\mathrm{CFI})$ and Normed Fit Index (NFI) are acceptable or marginally acceptable. The standardised root mean square residual (SRMR) is slightly above the 0.05 threshold. Taking into account all the above presented results, it can be concluded that the final model could be used to draw conclusions (Hsu, 2013).

The assessment of the final model is given in Table 3. Awareness can be modelled by the respondents' attitude towards CSR companies. The impact is such that the more the respondents are interested in having information on CSR activities of companies, the more they will recognise the socially responsible companies. The model has a low $\mathrm{R}$ square of just $6.3 \%$. 
Purchase intention and Trust can, on the other hand, be modelled with both attitude towards CSR and towards CSR companies. In the two equations, all predictors have a positive, statistically significant impact, and the impact of Attitude towards CSR companies is slightly stronger. The obtained R squares are high. Namely, $56.6 \%$ of the variability of Trust and $54.4 \%$ of the variability of Purchase intention can be explained by the respondents' attitude towards CSR and CSR companies.

Taking a look at the models of WOM and WTP, only Trust and Purchase intention have statistically significant and positive impacts. The more trust the respondents have and the higher their purchase intention is, the higher the price they are willing to pay and the more they are prepared to recommend the product/service. The R squares are high, $62.6 \%$ for the model of WOM and $60.8 \%$ for the model of WTP.

Table 3: Assessment of the final model: Construct, predictors, obtained standardised coefficients, C.R., and the R square

\begin{tabular}{|c|c|c|c|c|}
\hline Construct & Predictors & Std Coeff & C.R. & $\mathbf{R}^{2}$ \\
\hline Awareness & Attitude towards CSR companies & $0.252^{\star \star}$ & 3.600 & 0.063 \\
\hline \multirow{2}{*}{ Purchase intention } & Attitude towards CSR companies & $0.712^{\star \star}$ & 6.904 & \multirow{2}{*}{0.544} \\
\hline & Attitude towards CSR & $0.192^{\star}$ & 2.962 & \\
\hline \multirow{2}{*}{ Trust } & Attitude towards CSR companies & $0.683^{\star \star}$ & 6.602 & \multirow{2}{*}{0.566} \\
\hline & Attitude towards CSR & $0.315^{\star \star}$ & 4.697 & \\
\hline \multirow{2}{*}{ WOM } & Trust & $0.661^{* \star}$ & 7.207 & \multirow{2}{*}{0.626} \\
\hline & Purchase intention & $0.204^{\star}$ & 2.691 & \\
\hline \multirow{2}{*}{ WTP } & Trust & $0.542^{\star \star}$ & 6.372 & \multirow{2}{*}{0.608} \\
\hline & Purchase intention & $0.338^{*}$ & 4.244 & \\
\hline
\end{tabular}

Note: ${ }^{*} p<0.05,{ }^{* *} p<0.01$

\subsection{Discussion and managerial implications}

The obtained results show that the constructs Attitude towards CSR and Attitude towards CSR companies have a statistically significant impact on all modifying effects, except Awareness. Therefore, it can be said that hypothesis 1 is partially confirmed. This indicates that the more the respondents have a positive opinion on CSR and its importance, the more they will trust the CSR companies and consider buying products/services of CSR companies. Such information might be usefull for managers of CSR active companies as it provides reasurement that consumers pay attention to companies' CSR activities, value them, and shape their oppion on the company accordingly (Castaldo et al., 2009).

On the other hand, the same constructs do not have a statistically significant impact on both WTP and WOM, proving that hypothesis 2 is not confirmed. Therefore, the companies should be aware that for willingness to pay and recommend, it is not enough for the respondents to believe positively in CSR. These results are aligned with the results of Al Jarah and Emeagwali (2017) who came to the same conclusion after performing meta-analysis. Nevertheless, they should have in mind the indirect effect of attitudes towards CSR and CSR companies.

Both WTP and WOM can be successfully modelled by most defined Modifying effects, so we can conclude that the hypothesis 3 is partially confirmed. This hypothesis showed that for consumers to be willing to pay and recommend, they have to have enough trust and previous idea of purchasing products of CSR companies. The obtained results are in accordance with the results of Castaldo et al. (2009) and Perrini et al. (2010). The managerial implication which derives from these results is that if the company is to increase their sales and positive WOM, they should devote themselves to building trust with consumers based on their activities in the field of CSR.

The analysis of the test question provided more information about the perception of current market leaders when it comes to CSR. The priority conclusion is that the company DM Drogerie markt was identified by the largest number of respondents as socially responsible, and at the same time, it received the award for CSR from the Serbian Chamber of Commerce. This shows that the social initiatives of this company are very recognisable to consumers and that they appreciate and value them, but also that their projects are recognised by respected institutions in Serbia. However, companies Soko Stark, Delhaize and Telenor were among the top five most representative companies in terms of CSR, and none of them actually won the award. For these companies, it would be desirable to use this opinion among consumers to create new or apply for existing socially responsible initiatives in competitions of this type, such as the National Award for Corporate Social Responsibility. In that way, they would strengthen their reputation as companies which engage in CSR (Vlastelica Bakic, Krstovic \& Cicvaric Kostic, 2012). 
This paper aimed to create a conceptual model that would measure the influence of different factors on the decision to purchase products and services of socially responsible companies. The model is composed of six constructs: attitude towards social responsibility, attitude towards socially responsible companies, intention to buy, trust, willingness to pay, and word of mouth and one measured variable, Awareness. Also, the model was examined on the results of an online survey conducted in Serbia. The model verification shows that there are statistically significant relations between the proposed elements, that the consumers' attitude towards CSR and CSR active companies acts as a significant predictor of their trust and purchase intention, and that the consumers' WTP and WOM on products of CSR active companies are influenced by their level of trust and previous intention to buy. The detected relations could have managerial implications when it comes to doing business on the Serbian market.

It is of interest to observe how our results and conclusions align with previous studies on the topic of CSR conducted in Serbia. In their longitudinal study, Cockalo et al. (2015) show that the young population in Serbia and in the region is every year more and more acquainted with the term CSR and that they actively use the Internet to inform themselves on CSR and CSR active companies. Interestingly, they also point out that a high percentage of the respondents were not able to name a company operating on the domestic market which is socially responsible. Our study confirms that the trend initially observed by Cockalo et al. (2015) has not dramatically changed during the years, as the respondents are still interested in CSR, but cannot name and clearly recognize companies that are socially responsible.

On the other hand, Krstic, Trbovic and Draskovic (2018) find that the share of Serbian companies which apply some form of CSR is $75 \%$, which is significantly higher than the share of companies that possess CSR-related policies and procedures, which is $48 \%$. This confirms that there are more companies conducting CSR activities on paper than those applying CSR in a strategic and long-term manner. Based on their research findings, the same authors advocated changes in the education of managers. These results confirm one of our recommendations that the companies should be devoted to CSR activities in the long run to create trust and build purchase intention among consumers. This was also emphasised by Vlastelica Bakic, Cicvaric Kostic and Neskovic (2015) who stated that successful management of CSR helped achieve long-term benefits for the organization and the society in which it operateed.

This paper and the research can be further improved. Future research may focus on looking for reasons why consumers perceive companies that did not receive the "George Weifert" award as socially responsible and vice versa. The reasons for the existence of insufficient understanding and knowledge of the issue itself can be of different natures. There may be assumptions that in fact some companies, although communicating socially responsibly, are not socially responsible companies in general and therefore there is no basis for the "George Weifert" award. On the other hand, some companies may have been socially responsible, but for their own reasons, they did not compete for that award themselves. Also, there is a fear that respondents do not fully understand the meaning of the term CSR and they identify it with a subjective opinion about the company itself, its popularity and strength in the market. In the future, additional considerations in these directions may lead to an improvement of the model by including additional constructs relevant for the topic. The conducted analysis and the obtained results showed that it is possible to improve this model or create a new modified model for measuring the impact of corporate social responsibility on the purchase of sustainable products and services. Also, a possible limitation of the study is the relatively small sample size. In future studies, a larger part of the population could be covered.

Although several drawbacks of the research exist, the findings provided by our study can benefit companies that are engaged in CSR activities or plan to engage. The authors believe that the proposed conceptual model for exploring the effects of the consumers' perception of CSR activities could initiate further research on the topic and on future improvements of the models used to quantify the effectiveness of CSR activities

\section{REFERENCES}

[1] Abrantes Ferreira, D., Gonçalves Avila, M., \& Dias Faria, M. (2010). Corporate social responsibility and consumers' perception of price. Social Responsibility Journal, 6(2), 208-221. DOI:10.1108/17471111011051720

[2] Al Jarah, A., \& Emeagwali, O. L. (2017). Corporate social responsibility and behavioral intention: The moderator effect of contextual factors. Social Responsibility Journal, 13(4), 678-697. DOI:10.1108/SRJ07-2017-0113

[3] Almeida, M. da G. M. C., \& Coelho, A. F. M. (2019). The Antecedents of Corporate Reputation and Image and Their Impacts on Employee Commitment and Performance: The Moderating Role of CSR. Corporate Reputation Review, 22(1), 10-25. DOI:10.1057/s41299-018-0053-8

[4] Asparouhov, T., \& Muthén, B. (2009). Exploratory Structural Equation Modeling. Structural Equation Modeling: A Multidisciplinary Journal, 16(3), 397-438. DOI:10.1080/10705510903008204 
[5] Bansal, H. S., \& Voyer, P. A. (2000). Word-of-Mouth Processes within a Services Purchase Decision Context. Journal of Service Research, 3(2), 166-177. https://doi.org/10.1177/109467050032005

[6] Castaldo, S., Perrini, F., Misani, N., \& Tencati, A. (2009). The Missing Link Between Corporate Social Responsibility and Consumer Trust: The Case of Fair Trade Products. Journal of Business Ethics, 84(1), 1-15. DOI:10.1007/s10551-008-9669-4

[7] Chaffee, E. C. (2017). The origin of corporate social responsibility. University of Cincinnati Law Review, 85, 353-379.

[8] Cockalo, D., Djordjevic, D., Besic, C., \& Bogetic, S. (2015). Undergraduate business students' attitudes towards CSR and competitiveness of Serbian economy. Journal of engineering management and competitiveness (JEMC), 5(1), 12-20.

[9] Creyer, E. H., \& Ross, W. T. (1997). The influence of firm behavior on purchase intention: Do consumers really care about business ethics? Journal of Consumer Marketing, 14(6), 421-430. DOI:10.1108/07363769710185999

[10] Cronbach, L. J. (1951). Coefficient alpha and the internal structure of tests. Psychometrika, 16(3), 297334. DOI:10.1007/BF02310555

[11] Dahl, D. W., \& Lavack, A. M. (1995). Cause-Related Marketing: Impact of Size of Corporate Donation and Size of Cause-Related Promotion on Consumer Perceptions and Participation. AMA Winter Educators' Conference: Marketing Theory and Applications, (January 1995), 476-481.

[12] East, R., Hammond, K., \& Lomax, W. (2008). Measuring the impact of positive and negative word of mouth on brand purchase probability. International Journal of Research in Marketing, 25(3), 215-224. DOI:10.1016/j.jijresmar.2008.04.001

[13] Ekatah, I., Samy, M., Bampton, R., \& Halabi, A. (2011). The Relationship Between Corporate Social Responsibility and Profitability: The Case of Royal Dutch Shell PIc. Corporate Reputation Review, 14(4), 249-261. DOI:10.1057/crr.2011.22

[14] Holmes, J. H., \& Kilbane, C. J. (1993). Cause-related marketing: Selected effects of price and charitable donations. Journal of Nonprofit and Public Sector Marketing, 1(4), 67-83. DOI:10.1300/J054v01n04_05

[15] Hsu, L. (2013). Work motivation, job burnout, and employment aspiration in hospitality and tourism students-An exploration using the self-determination theory. Journal of Hospitality, Leisure, Sport \& Tourism Education, 13, 180-189. DOI:10.1016/j.jhlste.2013.10.001

[16] Jarvis, W., Ouschan, R., Burton, H. J., Soutar, G., \& O'Brien, I. M. (2017). Customer engagement in CSR: a utility theory model with moderating variables. Journal of Service Theory and Practice, 27(4), 833-853. DOI:10.1108/JSTP-04-2016-0081

[17] Kline, R. B. (2005). Principles and practice of structural equation modeling.

[18] Krstic, N., Trbovic, A., \& Draskovic, B. (2018). Evaluating the strategic approach to CSR in Serbia. Teme, 42(2), 503-521. DOI:10.22190/TEME1802503K

[19] Konuk, F. A. (2019). Consumers' willingness to buy and willingness to pay for fair trade food: The influence of consciousness for fair consumption, environmental concern, trust and innovativeness. Food Research International, 120, 141-147. DOI:10.1016/j.foodres.2019.02.018

[20] Maignan, I. (2001). Consumers' Perceptions of Corporate Social Responsibilities: A Cross-Cultural Comparison. Journal of Business Ethics, 30, 57-72. DOI:10.1023/A:1006433928640

[21] Manuel, T., \& Herron, T. L. (2020). An ethical perspective of business CSR and the COVID-19 pandemic. Society and Business Review, 15(3), 235-253. DOI:10.1108/SBR-06-2020-0086

[22] Maricic, M., \& Kostic-Stankovic, M. (2016). Towards an impartial Responsible Competitiveness Index: A twofold multivariate I-distance approach. Quality and Quantity, 50(1), 103-120. DOI:10.1007/s11135014-0139-z

[23] Maricic, M., Kostic-Stankovic, M., Bulajic, M., \& Jeremic, V. (2019). See it and believe it? Conceptual model for exploring the recall and recognition of embedded advertisements of sponsors. International Journal of Sports Marketing and Sponsorship, 20(2). DOI:10.1108/IJSMS-02-2018-0020

[24] Marin, L., \& Ruiz, S. (2007). "I Need You Too!" Corporate Identity Attractiveness for Consumers and The Role of Social Responsibility. Journal of Business Ethics, 71(3), 245-260. DOI:10.1007/s10551006-9137-y

[25] Marquina, P., \& Morales, C. E. (2012). The influence of CSR on purchasing behaviour in Peru and Spain. International Marketing Review, 29(3), 299-312. DOI: 10.1108/02651331211229778

[26] McIntyre, N., \& Pigram, J. J. (1992). Recreation specialization reexamined: The case of vehicle-based campers. Leisure Sciences, 14(1), 3-15. DOI:10.1080/01490409209513153

[27] Mohr, L. A., \& Webb, D. J. (2005). The effects of corporate social responsibility and price on consumer responses. Journal of Consumer Affairs, 39(1), 121-147. DOI:10.1111/j.1745-6606.2005.00006.x

[28] Perrini, F., Castaldo, S., Misani, N., \& Tencati, A. (2010). The impact of corporate social responsibility associations on trust in organic products marketed by mainstream retailers: a study of Italian consumers. Business Strategy and the Environment, 19(8), 512-526. DOI:10.1002/bse.660 
[29] Pivato, S., Misani, N., \& Tencati, A. (2007). The impact of corporate social responsibility on consumer trust: the case of organic food. Business Ethics: A European Review, 17(1), 3-12. DOI:10.1111/j.14678608.2008.00515.x

[30] Porter, M., \& Kramer, M. (2006). Strategy and society: the link between competitive advantage and corporate social responsibility. Harvard Business Review, 84(12), 78-92.

[31] Privredna komora Srbije. (2020). Nacionalna nagrada za društveno odgovorno poslovanje. Retrieved October 10, 2020, from https://pks.rs/strana/nacionalna-nagrada-za-dop

[32] Ramesh, K., Saha, R., Goswami, S., Sekar, \& Dahiya, R. (2019). Consumer's response to CSR activities: Mediating role of brand image and brand attitude. Corporate Social Responsibility and Environmental Management, 26(2), 377-387. DOI:10.1002/csr.1689

[33] Rim, H., \& Kim, S. (2016). Dimensions of corporate social responsibility (CSR) skepticism and their impacts on public evaluations toward CSR. Journal of Public Relations Research, 28(5-6), 248-267. DOI:10.1080/1062726X.2016.1261702

[34] Smith, G. (2008). Does gender influence online survey participation?: A record-linkage analysis of university faculty online survey response behavior.

[35] Stotlar, D. K. (1993). Sponsorship and the Olympic games. Sport Marketing Quarterly, 1(1), 35-43.

[36] Tavakol, M., \& Dennick, R. (2011). Making sense of Cronbach's alpha. International Journal of Medical Education, 2, 53-55. DOI:10.5116/ijme.4dfb.8dfd

[37] Vlastelica Bakic, T., Krstovic, J., \& Cicvaric Kostic, S. (2012). Poslovna opravdanost društveno odgovornog poslovanja. Marketing, 43, 191-197. UDK 347.72.032:005.35

[38] Vlastelica Bakic, T., Cicvaric Kostic, S., \& Neskovic, E. (2015). Model for managing corporate social responsibility. Management, 222(74), 47-56. DOI: 10.7595/management.fon.2015.0002

[39] Weber, M. (2008). The business case for corporate social responsibility: A company-level measurement approach for CSR. European Management Journal, 26(4), 247-261. DOI:10.1016/j.emj.2008.01.006

[40] Yu, C. L., \& Tang, X. (2010). The Construct and Influence of Word of Mouth: Receiver Perspectives. Marketing Science Innovations and Economic Development, 182-186.

[41] Zeithaml, V. A., Berry, L. L., \& Parasuraman, A. (1996). The Behavioral Consequences of Service Quality. Journal of Marketing, 60(2), 31-46. DOI:10.2307/1251929

Received: 2020-12-19

Revisions requested: 2021-02-09

Revised: 2021-02-16

Accepted: 2021-03-25

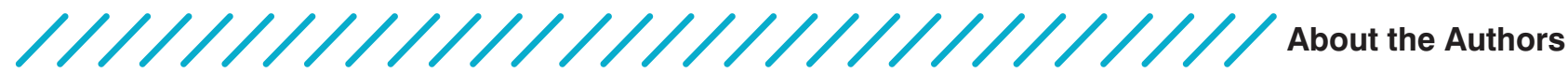

\section{University of Belgrade, Faculty of Organizational Sciences, Serbia nikolic.milica@mail.com}

Milica Nikolić is a master's student of Informational Technologies at the University of Belgrade, Faculty of Organizational Sciences. She completed her undergraduate studies of Informational Systems and Technologies at the University of Belgrade, Faculty of Organizational Sciences. Her fields of interest are data analysis, product management and human-computer interaction.

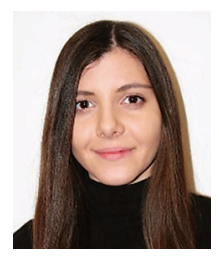

Milica Maričić University of Belgrade, Faculty of Organizational Sciences, Serbia milica.maricic@fon.bg.ac.rs

Milica Maričić is an assistant professor at the University of Belgrade, Faculty of Organizational Sciences. She received her Ph.D. at the same faculty, in the field of Computational Statistics. She specializes in the field of applied statistics and data analysis. Her research interests include the development and evaluation of ranking methodologies, structural equation modelling, and multivariate analysis. She has published more than 40 scientific papers with an emphasis on ISI indexed journals. She is an active member of the International Statistical Institute (ISI).

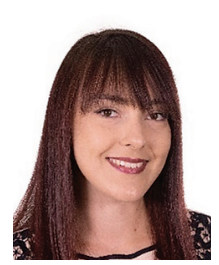


Dejana Nikolić

University of Belgrade, Faculty of Organizational Sciences, Serbia dejana.nikolic@fon.bg.ac.rs

Dejana Nikolic is a Teaching Assistant at the Univeristy of Belgrade, Faculty of Organizational Sciences, Department of Marketing Management and Public

Relations. She is also a PhD student at the University of Belgrade, Faculty of Organizational Sciences. Her research fields are creative industries, marketing and public relations. She is also the author of more than 30 scientific papers in the field of management and communications.

\section{Appendix}

Questions used to quantify the conceptual model constructs alongside the source from which the questions were adapted from

\section{Attitude towards CSR}

Questions

CSR is important for the company's business

CSR affects the sales rate of products and services

CSR contributes to building trust between the company and its consumers

CSR is a necessity in today's business

CSR enhances the society's economic development

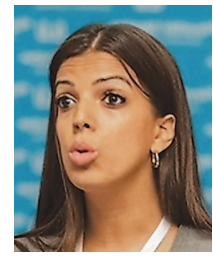

Attitude towards CSR companies

\begin{tabular}{|l|l|}
\hline Questions & Sources \\
\hline I have a positive attitude towards companies that are socially responsible & \\
CSR improves my attitude towards companies and their products/services & Maricic et al. \\
I think companies build their brand through social responsibility & $(2019)$ \\
It is important for me to be informed which companies are socially responsible & \\
I think that the companies are obliged to be socially responsible & Authors \\
\hline I regularly follow the social networks of socially responsible companies & \\
\hline
\end{tabular}

\section{Purchase intention}

\begin{tabular}{|l|l|}
\hline Questions & Source \\
\hline When buying products/services, I will give preference to a socially responsible & \\
company & Konuk (2019) \\
I would like to try a product/service of a socially responsible company & \\
I regularly buy products/services of companies which are socially responsible & \\
\hline
\end{tabular}

Trust

Questions

I believe more in the quality of products/services of socially responsible companies

I believe that by purchasing the products/services of a socially responsible company,

I am helping the community

I believe that by purchasing the products/services of a socially responsible company

I will contribute to the development of awareness of the importance of CSR

\section{Willingness to pay (WTP)}

Questions

I am ready to pay more for a product/service because it is produced by a socially responsible company

I would buy products/services of socially responsible companies even if their competitors had significantly lower prices

I am ready to pay more for a product/service of a socially responsible company because I believe that in that way I contribute to the community

Word of Mouth (WOM)

Questions

I encourage people to buy products/services of socially responsible companies

I encourage my friends to buy products/services of socially responsible companies

I recommend companies that are socially responsible in my business environment
Sources

Castaldo et al. (2009)

Pivato et al. (2007)

Sources

Zeithaml et al. (1996)

Castaldo et al. (2009)) 